\section{Detection of BVD/MD}

I read the recent publication on detection of BDV/MD with a great interest ${ }^{1}$. Njiro et al. concluded that 'The IHC procedure located BVD/MD viral antigen in a wide variety of foetal tissues including cerebral cortical neurons, the pseudostratified columnar epithelial cells lining the bronchi, alveolar lining cells and alveolar macrophages, hepatocytes, renal tubular lining cells and the Purkinje fibres in the myocardium.'
I agree that this IHC can be a good diagnostic test. However, there are some points of concern. First, the importance of quality control in specimen preparation (preanalytical phase) and the analytical procedure should be noted. A problem with quality can be expected in any IHC procedure $^{2}$. Second, the number of subjects in this work are few, hence this might lead to limitations in the assessment of sensitivity and specificity of the test.
Furthermore, comparative studies with other techniques such as microbiological tests might be useful.

\section{References}

1. Niiro S M, Nkosi C M 2009 Detection of the bovine viral diarrhoea/mucosal disease (BVD/MD) virus in tissues from aborted ruminant foetuses using immunohistochemistry. Journal of the South African Veterinary Association 80: 229-232

2. True L D 2008 Quality control in molecular immunohistochemistry. Histochemical Cell Biology 130: $473-480$

\title{
V Wiwanitkit
}

